\title{
Model Edukasi Kreatif Pesantren Melalui Pemanfaatan E-Learning Di Era Digital
}

\author{
Rila Setyaningsih, Abdullah, Edy Prihantoro dan Hustinawaty \\ Ilmu Komunikasi Universitas Darussalam Gontor \\ Pascasarjana Ilmu Komunikasi Universitas Gunadarma \\ Email: rilasetya@unida.gontor.ac.id \\ Email: abdullah@unida.gontor.ac.id \\ Email: edipri@staff.gunadarma.ac.id \\ Email: hustina@staff.gunadarma.ac.id
}

\begin{abstract}
The digital era which is characterized by the development of ICT (Information and Communication Technology) requires the process of learning and teaching in universities to be adjusted, not least at pesantren-based universities. The internet-based learning system or e-learning developed in the Communication Study Program of University of Darussalam Gontor aims to facilitate the learning process on campus both for lecturers as instructors and for students who are taught. Through e-learning students not only get textual material, but visual material such as image, video and animation also clarify understanding of the material. The purpose of this study was to find out the creative education model of University of Darussalam Gontor as one of the pesantren(boarding school) universities through the use of e-learning in the digital era. Data collection was conducted through observation and interviews with lecturers of Communication Studies ProgramOf University of Darussalam Gontor. The results of this study are a model of pesantren creative education through e-learning in the digital era. The uploaded learning content in e-learning consists of several forms such as material (in the form of power points, short videos, images, animation, etc.), quizzes, and also discussion forums as a means of communication between lecturers and students through virtual classes without having to meet advance.
\end{abstract}

Keywords:e-learning, creative education, digital era, model, pesantren.

\begin{abstract}
Abstrak
Era digital yang ditandai dengan perkembangan TIK (Teknologi Informasi dan Komunikasi) mengharuskan proses belajar dan mengajar di perguruan tinggi untuk disesuaikan, tidak terkecuali di universitas berbasis pesantren. Sistem pembelajaran berbasis internet atau e-learning yang dikembangkan di Program Studi Ilmu Komunikasi Universitas Darussalam Gontor bertujuan untuk memudahkan proses pembelajaran di kampus baik untuk dosen sebagai pengajar maupun bagi mahasiswa yang diajar. Melalui e-learning mahasiswa tidak hanya mendapatkan materi secara tekstual saja, tetapi materi yang berupa visual seperti image, video dan animasi juga memperjelas pemahaman terhadap materi. Tujuan penelitian ini untuk mengetahui model edukasi kreatif Universitas Darussalam Gontor sebagai salah satu universitas pesantren melalui pemanfaatan e-learning di era digital. Metode yang digunakan dalam penelitian ini adalah deskriptif kualitatif. Pengumpulan data dilakukan melalui observasi dan wawancara dengan dosen-dosen Program Studi Ilmu Komunikasi Universitas Darussalam Gontor.Hasil dari penelitian ini berupa model edukasi kreatif pesantren melalui e-learning di era digital. Konten pembelajaran yang di-upload di e-learning terdiri dari beberapa bentuk seperti
\end{abstract}


materi (berupa power point, video pendek, gambar, animasi, dll), kuis, dan juga forum diskusi sebagai sarana komunikasi antara dosen dan mahasiswa melalui kelas virtual tanpa harus bertatap muka.

Kata Kunci:e-learning, edukasi kreatif, era digital, model, pesantren.

\section{Pendahuluan}

Era digital yang ditandai dengan pesatnya perkembangan TIK (Teknologi Informasi dan Komunikasi) telah membawa perubahan yang dahsyat dalam kehidupan sosial dan budaya masyarakat. Munculnya teknologi informasi dan komunikasi mampu menghapuskan batasbatas ruang dan waktu. Friedman (2007) menggambarkannya dengan "the world is flat". Hal inilah yang menyebabkan manusia dapat terkoneksi dengan siapa saja, kapan saja, dan dimana saja.

Munculnya era digital juga berakibat pada pergeseran model pembelajaran dalam dunia pendidikan. Pembelajaran di beberapa instansi pendidikan yang dulu terbatas pada penggunaan buku tekstual kini telah menyesuaikan diri dengan model pembelajaran kontekstual melalui pemanfaatan media digital dalam proses pembelajaran. Hal ini juga dilakukan oleh pendidikan tinggi di pesantren modern.

Berbeda dengan pesantren tradisional, pesantren modern telah melakukan pembaharuan secara lebih mendasar karena telah ditemukan beberapa kelemahan pada pendidikan pesantren tradisional. Menurut Imam Zarkasyi salah satu kelemahan pesantren tradisional adalah dalam bidang kurikulum yang hanya mengajarkan pengetahuan agama, sehingga lulusannya tidak dapat memasuki lapangan kerja yangmensyaratkan memiliki pengetahuan umum, penguasaan teknologi dan keterampilan (Nurhakim, 2011:86).Adapun pesantren modern telah memadukan pengetahuan agama dan pengetahuan umum dalam kurikulumnya disamping juga pendidikan karakter sebagai ikon yang menjiwainya.

Munculnya perkembangan teknologi juga menjadi sebuah tantangan baru bagi model pengajaran di pesantren. Lembaga pendidikan pesantren yang telah sejak lama menerapkan model pendidikan tekstual dengan mempelajari kitab-kitab dengan model sorogan, kini mengahadapi tantangan baru di era digital. Kondisi ini menuntut lembaga pendidikan pesantren khususnya perguruan tinggi pesantren untuk menyesuaikan diri.

Disamping itu, pendidikan abad 21 juga memiliki tuntutan bahwa pendidikan harus senantiasa bergerak sejalan dengan kemajuan zaman (Trilling \& Fadel, 2009).Pendidikan abad 21 memiliki tujuan untuk mendorong peserta didik agar menguasai keterampilan abad 21 sehingga lebih responsif terhadap perkembangan dan perubahan zaman.Adapun salah satu domain yang sangat penting dalam pendidikan abad 21 adalah Digital-Age Literacy.

Konskuensi dari munculnya era digital dalam dunia pendidikan termasuk juga pendidikan tinggi adalah berupa desain pembelajaran dengan memanfaatkan media digital sebagai sarana untuk meningkatkan pengetahuan mahasiswa. Lembaga pendidikan tinggi pesantren sebagai bagian dari lembaga pendidikan tinggi sudah selayaknya menyesuaikan diri untuk menyelenggarakan proses pembelajaran berbasis digital.

Program Studi Ilmu Komunikasi Universitas Darussalam Gontor sebagai salah satu pedidikan tinggi berbasis pesantren terus berusaha untuk mengikuti perkembangan zaman dan menyiapkan lulusan yang mampu bersaing dalam dunia kerja serta menguasai teknologi informasi dan komunikasi. Upaya ini dilakukan sebagai bentuk implementasi dari salah satu motto universitas yakni "berpengetahuan luas".

Berdasarkan latar belakang yang ada, penelitian tentang model edukasi kreatif pesantren melalui pemanfaatan e-learning di era digital menjadi pembahasan yang penting dan 
menarik untuk didiskusikan. Penelitian ini akan memberikan kontribusi terhadap model edukasi kreatif yang dapat diterapkan di pesantren khususnya pada tingkat pendidikan tinggi yang menerapkan sistem pesantren dengan memanfaatkan e-learning dalam pembelajaran di era digital.

Pembelajaran yang kreatif dengan memanfaatkan media digital dalam dunia pendidikan termasuk juga pendidikan tinggi pesantren menjadi sebuah tuntutan di era digital sekarang ini. Terdapat beberapa penelitian yang sudah dilakukan dengan fokus pendidikan di era digital. Wijaya, Sudjimat, dan Nyoto melakukan penelitian pada tahun 2016 dengan judul "Transformasi Pendidikan Abad 21 Sebagai Tuntutan Pengembangan Sumber Daya Manusia Di Era Global". Penelitian dilakukan dengan tujuan untuk mendeskripsikan kompetensi abad21 yang dibutuhkan di dunia usaha/ dunia industri bidang pekerjaan sebagai teknisi jaringan. Hasil penelitian menunjukkan bahwa kebutuhan dunia kerja dan industri di era digital meliputi: (1) keterampilan dan belajar berinovasi; (2) kehidupan dan karir; dan (3) keterampilan teknologi dan media informasi.

Penelitian lain dilakukan oleh Hamied pada tahun 2009 dengan judul "Model Pembelajaran Inovatif Di Era Global (Suatu Kajian Perbandingan Di Negara Maju)". Penelitian dilakukan dengan tujuan melihat kembali masalah pendidikan di Indonesia, kemudian mencoba menemukan masalah apa yang disebabkan globalisasi, dan akhirnya akan membahas teknologi apa yang digunakan dalam pendidikan dan pengajaran. Disamping itu juga akan membahas kebijakan apa yang telah atau sedang dibuat oleh pemerintah dalam kaitannya dengan teknologi informasi dan telekomunikasi. Hasil penelitian menunjukkan bahwa salah satu model yang telah banyak digunakan di beberapa negara maju dan berkembang seperti Indonesia berupa model pembelajaran aktif.

Disamping penelitian tentang pembelajaran di era digital, penelitian e-learning juga telah banyak dilakukan antara lain oleh Barokati dan Annas pada tahun 2013 dengan judul "Pengembangan Pembelajaran Berbasis Blended Learning Pada Mata Kuliah Pemrograman Komputer (Studi Kasus: UNISDA Lamongan)". Pada penelitian ini, mata kuliah Pemrograman Komputer dijadikan salah satu uji coba pertama dalam implementasi e-learning. Hasil penelitian menunjukkan bahwa Mata kuliah Pemrograman Komputer yang telah diterapkan di UNISDA terdapat beberapa perbedaan yang lebih baik bila dibandingkan dengan sebelum implementasi e-learning.

Penelitian lain dilakukan oleh Agustina pada tahun 2013 dengan judul "Pemanfaatan E-learning Sebagai Media Pembelajaran". Penelitian dilakukan dengan tujuan untuk mengetahui pemanfaatn e-learning dalam pembelajaran dan faktor-faktor yang mempengaruhi di Universitas Bina Darma Palembang. Hasil penelitian menunjukkan bahwa kondisi pemanfaatan e-learning sebagai media pembelajaran di Universitas Bina Darma berada pada kondisi cukup baik dengan tingkat presentase sebesar $60 \%$.

Kedua penelitian tentang pembelajaran di era digital menunjukkan bahwa perlu adanya transformasi dan inovasi serta kretivitas dalam melaksanakan pembelajaran di era digital dengan memanfaatkan media digital serta active learning.Hal itu penting dilakukan karena tuntutan dunia kerja saat ini berupa lulusan perguruan tinggi yang memiliki daya saing, kompetensi, inovatif, serta menguasai teknologi. Adapun dua penelitian tentang e-learning yang dilakukan Agustina (2013) dan Barokati \&Annas (2013) menunjukkan bahwa pembelajaran dengan memanfaatkan media digital berupa e-learning menjadi hal yang urgent untuk dilakukan di perguruan tinggi guna mengikuti perkembangan teknologi informasi saat ini. Pemanfaatan e-learning merupakan salah satu model pembelajaran kreatif di perguruan tinggi pesantren, hal ini karena munculnya era digital menuntut lembaga pendidikan untuk menyesuaikan diri dari pembelajaran model tekstual menjadi kontekstual. Model edukasi 
kreatif merupakan salah satu bentuk inovasi yang dilakukan perguruan tinggi pesantren dalam menyesuaikan diri dengan perkembangan TIK. Fokus dalam tulisan ini membahas tentang model edukasi kreatif pesantren melalui pemanfaatan e-learning di era digital. Adapun pesantren yang dimaksud dalam penelitian ini adalah UNIDA Gontor (Universitas Darussalam Gontor). Perguruan Tinggi UNIDA Gontor sebagai salah satu universitas pesantren terbesar di Jawa Timur berupaya dalam menyesuaikan diri untuk melakukan pembelajaran yang kreatif dengan memanfaatkan e-learning. Pemanfaatan e-learning dilakukan dengan cara pengembangan konten pembelajaran pada mata kuliah dasar (Pengantar Ilmu Komunikasi, Teori Komunikasi, Psikologi Komunikasi, Komunikasi Kontekstual, dan Komunikasi Massa) di Program Studi Ilmu Komunikasi Universitas Darussalam Gontor.

Edukasi kreatif atau pembelajaran kreatif dalam penelitian ini berasal dari definisi berfikir kreatif menurut Goleman, dkk (2005) yang kemudian di adopasi dan diadaptasi ke dalam model pembelajaran kreatif. Adapun langkah dalam pembelajaran yang kreatif yaitu: 1). Tahap pertama persiapan, pada tahap ini membiarkan imajinasi bebas, membuka diri pada apapun dan secara samar-samar relevan dengan permasalahan. Tujuannya adalah untuk mengumpulkan unsur yang tidak biasa dan tidak terduga bisa dengan sendirinya muncul berdampingan, 2). Tahap kedua inkubasi, pada tahap ini merenungkan seluruh potongan yang relevan dan mendesakkan pikiran rasional ke batas terjauhnya. Pada tahap ini persoalan dibiarkan mengendap. 3). Tahap ketiga adalah pencerahan, pada tahap ini jawaban yang dicari datang, inilah biasanya tahap yang memperoleh perhatian. 4). Tahap terakhir adalah penerjemahan, pada tahap ini dilakukan pengubahan wawasan menjadi tindakan.

Kreatifitas bukan sebuah kemampuan tunggal yang bisa digunakan seseorang dalam setiap aktivitas. Terdapat tiga bahan kreatifitas (Teresa dalam Goleman dkk, 2005) yaitu: 1). Keahlian dalam bidang khusus berupa keterampilan dalam hal tertentu, keterampilan ini merupakan penguasaan dasar dalam suatu bidang, 2). Keterampilan berfikir kreatif, mencakup kemampuan untuk membayangkan rentang kemungkinan yang beragam, tekun dalam menangani persoalan, dan memiliki standar kerja yang tinggi. 3). Motivasi instrinsik, merupakan dorongan untuk melakukan sesuatu semata demi kesenangan melakukannya, bukan karena kompensasi atau hadiah.

Dalam penelitian ini pembelajarn kreatif merupakan upaya yang dilakukan oleh dosen pengampu mata kuliah dasar di Program Studi Ilmu Komunikasi UNIDA Gontor untuk membuat konten pembelajaran yang menarik dan inovatif dalam bentuk power point, gambar, animasi, video dan lain sebagainya yang kemudian di upload dalam portal e-learning. Disamping materi, dosen pengampu mata kuliah dasar di Program Studi Ilmu Komunikasi UNIDA Gontor juga upload soal pre-test dan post-test serta forum yang dapat dimanfaatkan untuk melakukan diskusi secara virtual antara dosen dengan mahasiswa peserta kuliah.

Pesantren merupakan lembaga pendidikan Islam dengan sistem asrama, Kyai sebagai central figurnya, masjid sebagai titik pusat yang menjiwainya (Staff Sekretaris PMDG, 2017: 2). Universitas Darussalam Gontor merupakan perguruan tinggi berbasis pesantren yang menerapkan sistem asrama dan rektor sebagai Kyai yang merupakan central figur.

Universitas Darussalam Gontor sebagai perguruan tinggi pesantren memiliki Panca Jiwa yang terdiri dari: (1). jiwa keikhlasan, tidak ada satu fihakpun yang mempunyai niatan atau keinginan untuk memperoleh imbalan jasa berupa material, (2). jiwa kesederhanaan, bukanlah berarti pasif dan bukan juga melarat atau miskin, kesederhanaan berarti bersikap tepat dalam situasi dan kondisi yang sesuai pula. (3) berdikari, bukan saja berarti bahwa santri atau mahasiswa selalu belajar dan berlath mengurus segala kepentingannya sendiri tetapi juga Pondok Pesantren itu sendiri sebagai lembaga pendidikan tidak pernah menyandarkan 
kehidupannya kepada bantuan atau belas kasihan orang lain. (4) jiwa ukhuwwah Islamiyyah, yaitu rasa kekeluargaan dan kebersamaan dalam menjalani hidup di pondok maupun diluar pondok pesantren. dan (5) jiwa bebas, bebas dari pengaruh siapapun karena Gontor berdiri atas dan untuk semua golongan. E-Learning merupakan sistem
pembelajaran berbasis internet. Sistem E-Learning diharapkan bukan sekedar menggantikan tetapi diharapkan pula untuk dapat menambahkan metode dan materi pengajaran tradisional seperti diskusi dalam kelas, buku, CD-ROM dan pelatihan komputer non internet. Berbagai elemen yang terdapat dalam sistem E-Learning adalah: (1). Materi : materi kuliah disajikan dengan power point yang berisi pointpoint materi kuliah namun disajikan dengan tampilan yang menarik, ditambah gambar, suara, dan video. (2). Soal-soal : terdapat soalsoal yang berisi pertanyaan untuk evaluasi pembelajaran. Soal yang disediakan lengkap dengan kunci jawaban dan skor akhir sehingga mahasiswa dapat mengukur penguasaan terhadap materi. (3). Komunitas : para mahasiswa dapat mengembangkan komunitas online untuk memperoleh dukungan dan berbagi informasi yang saling menguntungkan. (4). Pengajar online : para dosen selalu online untuk memberikan arahan kepada para mahasiswa, menjawab pertanyaan dan membantu dalam diskusi. (5). Kesempatan bekerja sama : Adanya perangkat lunak yang dapat mengatur pertemuan online sehingga belajar dapat dilakukan secara bersamaan atau real time tanpa kendala jarak. (6). Multimedia : penggunaan teknologi audio dan video dalam penyampaian materi sehingga menarik minat dalam belajar.

E-learning diharapkan dapat menunjang peningkatkan mutu pendidikan khususnya pendidikan tinggi dan institusi yang relatif telah memiliki fasilitas jaringan komputer. Pengembangan pendidikan menuju e-learning merupakan suatu keharusan agar standar mutu pendidikan dapat ditingkatkan. E-learning dapat menghadirkan pembelajaran dengan kreteria (1) merupakan jaringan dengan kemampuan untuk memperbaharui, menyimpan, mendistribusikan serta membagi materi ajar berbasis TIK, (2) pengiriman kepada pengguna terakhir melalui jaringan komputer menggunakan teknologi internet yang standart, (3) memfokuskan pada suatu pandangan yang paling luas tentang pembelajaran dibalik paradigma pembelajaran tradisional (Rosenberg, 2001:28).

Sistem pembelajaran berbasis internet atau e-learning yang dikembangkan di Prodi Ilmu Komunikasi UNIDA Gontor bertujuan untuk memudahkan proses pembelajaran di kampus baik untuk dosen sebagai pengajar maupun bagi mahasiswa yang diajar. Proses pembelajaran seperti ini bisa dilakukan dimana saja tidak harus di kampus. Interaksi virtual dengan memanfaatkan teknologi informasi tidak mengharuskan peserta ajar (mahasiswa) duduk di satu ruangan selalu mendapatkan materi. E-learning merupakan pengajaran intern yang membantu pengajar memanfaatkan waktu, fasilitas, teknologi dalam usahanya dalam meningkatkan proses pengajaran. Inovasi dan pengembangan metode atau proses pengajaran yang berbasis E-learning dapat menghasilkan tingkat pemahaman mahasiswa yang lebih baik. Melalui e-learning mahasiswa tidak hanya mendapatkan materi secara tekstual saja, tetapi materi yang berupa visual seperti image, video dan animasi juga memperjelas pemahaman terhadap materi. Keberhasilan dari program pembelajaran ini dapat dilihat dari meningkatnya pemahaman mahasiswa terhadap mata kuliah yang di e-learning-kan.

\section{Metode Penelitian}

Penelitian ini menggunakan metode kualitatif untuk menggali pembelajaran kreatif yang telah dilakukan pesantren dalam hal ini Universitas Darussalam Gontor melalui pemanfaatan e-learning di era digital. Data dalam penelitian ini diperoleh melalui observasi secara langsung serta wawancara mendalam.Observasi dilakukan di Program Studi Ilmu Komunikasi Universitas Darussalam Gontor sebagai tempat 
dikembangkannya e-learning.Wawancara dilakukan dengan dosen-dosen di Program Studi Ilmu Komunikasi UNIDA Gontor sebagai subjek penelitian.Jumlah subjek penelitian terdiri dari 5 orang pengampu mata kuliah dasar yakni mata kuliah Pengantar Ilmu Komunikasi, Teori Komunikasi, Psikologi Komunikasi, Komunikasi Kontekstual, dan Komunikasi Massa.

Setelah melakukan observasi dan wawancara mendalam, peneliti kemudian mengkonstruksi pesan-pesan yang didapat dari informan.Setelah menggali pemanfaatan e-learning dalam proses pembelajaran yang dilakukan oleh para dosen Prodi IlmuKomunikasi UNIDA Gontor, peneliti kemudian memetakan pemanfaatan e-learning sebaga imodel edukasi kreatif yang terdiri dari keahlian, keterampilan, dan motivasi intrinsik dalam proses pembelajaran yang dilakukan oleh lima orang dosen Program Studi Ilmu Komunikasi Universitas Darussalam Gontor sebagai subjek penelitian.

\section{Hasil dan Pembahasan Penelitian}

Penelitian dengan judul "Model Edukasi Kreatif Pesantren Melalui Pemanfaatan E-Learning di Era Digital" ini merupakan hasil penelitian yang dilakukan dengan menggunakan metode deskriptif kualitatif dengan latar alamiah sebagai keutuhan.Peneliti melakukan observasi secara langsung dan wawancara mendalam kepada subjek penelitian.Peneliti melakukan observasi secara langsung dengan melihat dan mengamati kegiatan pelatihan upload konten pembelajaran yang dilakukan oleh dosen-dosen yang mengampu mata kuliah dasar di Program Studi Ilmu Komunikasi. Dari pengamatan yang dilakukan peneliti, ditemukan bahwa selama ini kegiatan pembelajaran yang dilakukan oleh dosen-dosen Program Studi Ilmu Komunikasi UNIDA Gontor sudah memanfaatkan media digital akan tetapi belum maksimal. Pemanfaatan e-learning dalam proses pembelajaran merupakan salah satu bentuk model edukasi kreatif di Universitas Darussalam Gontor sebagai sebuah perguruan tinggi berbasis pesantren.

Edukasi kreatif harus berangkat dari 3 hal yaitu: 1). Keahlian dalam bidang khusus berupa keterampilan dalam hal tertentu, keterampilan ini merupakan penguasaan dasar dalam suatu bidang, 2). Keterampilan berfikir kreatif, mencakup kemampuan untuk membayangkan rentang kemungkinan yang beragam, tekun dalam menangani persoalan, dan memiliki standar kerja yang tinggi. 3). Motivasi instrinsik, merupakan dorongan untuk melakukan sesuatu semata demi kesenangan melakukannya, bukan karena kompensasi atau hadiah(Teresa dalam Goleman dkk, 2005). Edukasi kreatif dalam penelitian ini berupa pemanfaatan e-learning sebagai sebuah media digital.

Adapun yang dimaksud media digital adalahsalahsatu gadget dalam media baru, u Komunikasi dan Komodifikasi dijelaskan definisi media baru (Dennis McQuail, 2000) terdapat empat kategori utama yaitu: 1). Media komunikasi interpersonal seperti email, 2). Media permainan interaktif seperti game, 3). Media pencarian informasi seperti mesin pencarian di Net, dan 4). Media partisipatoris, seperti ruang chat di Net.

Dalam penelitian ini yang dimaksud dengan edukasi kreatif adalah kesiapan dosen pengampu mata kuliah dasar di Program Studi Ilmu Komunikasi UNIDA Gontor dalam memanfaatkan media digital berupa e-learning yang terdiri dari keahlian menggunakan e-learning dalam proses pembelajaran, keterampilan dalam mengembangkan konten pembelajaran, dan motivasi intrinsik untuk melakukan inovasi dalam pembelajaran yaitu dengan memanfaatkan e-learning.

Untuk mengetahui model pembelajaran kreatif oleh dosen-dosen Program Stud illmu Komunikasi UNIDA Gontor melalui pemanfaatan e-learning, dalam penelitian ini akan dikaji berdasarkan kriteria berfikir kreatif Goleman dkk yang telah diadopsi dan disesuaikan kedalam pembelajaran kreatif dengan memanfaatkan media digital berupa e-learning. Adapun kriteria tersebut terdiri dari tiga komponen yaitu keahlian, keterampilan, dan motivasi intrinsik. 
Komponen pertama keahlian bidang khusus berupa keterampilan dalam hal tertentu, keterampilan ini merupakan penguasaan dasar dalam suatu bidang. Dalam penelitian ini yang dimaksud keahlian adalahkemampuan subjek penelitian dalam memanfaatkan e-learning dalam proses pembelajaran sebagai bentuk edukasi kreatif.Keahlian merupakan kemampuan untuk mengoperasikan media. Keahlian mencakup beberapa kriteria, yaitu kemampuan menggunakan media (media skills), kemampuan menggunakan media secara aktif (balanced and active use of media), dan kemampuan menggunakan dan pemanfaatan media secara tinggi (advanced media use). Dalam penelitian ini dikaji tentang kemampuan subjek penelitian dalam mengoperasikan e-learning serta memanfaatkan konten-konten yang ada di portal e-learning.

Berdasarkan hasil penelitian diketahui bahwa subjek penelitian yakni dosen-dosen program studi Ilmu Komunikasi Universitas Darussalam Gontor sudah mampu menggunakan dan memanfaatkan e-learning dalam proses pembelajaran. E-learning merupakan media pembelajaran yang mampu mengakomodir konsep pembelajaran virtual secara lengkap. Dalam e-learning yang dikembangkan di Program Studi Ilmu Komunikasi UNIDA Gontor terdapat konten materi, forum sebagai media diskusi antara dosen dengan para mahasiswa, dan juga kuis/ soal latihan. Dengan adanya e-learning materi pembelajaran dosen dapat terdokumentasi dengan lebih baik. E-learning akan sangat membantu meningkatkan keahlian literasi digital para dosen dikarenakan kegiatan pembelajaran dapat dilakukan secara virtual tanpa harus bertatap muka di kelas.

Berdasarkan hasil penelitian diketahui bahwa subjek penelitian yakni dosen-dosen program studi Ilmu Komunikasi Universitas Darussalam Gontor sudah mampu menggunakan dan memanfaatkan e-learning dalam proses pembelajaran. E-learning merupakan media pembelajaran yang mampu mengakomodir konsep pembelajaran virtual secara lengkap.
Dalam e-learning yang dikembangkan di Program Studi Ilmu Komunikasi UNIDA Gontor terdapat konten materi, forum sebagai media diskusi antara dosen dengan para mahasiswa, dan juga kuis/ soal latihan. Dengan adanya e-learning materi pembelajaran dosen dapat terdokumentasi dengan lebih baik. E-learning akan sangat membantu meningkatkan level use skill literasi digital para dosen dikarenakan kegiatan pembelajaran dapat dilakukan secara virtual tanpa harus bertatap muka di kelas.

Komponen kedua adalah keterampilan yang mencakup kemampuan untuk membayangkan rentang kemungkinan yang beragam, tekun dalam menangani persoalan, dan memiliki standar kerja yang tinggi. Dalam penelitian ini yang dimaksud keterampilan adalah kemampuan subjek penelitian dalam mengembangkan konten pembelajaran dan menciptakan pembelajaran yang aktif. Terdapat 5 mata kuliah dasar yang dikembangkan yakni Pengantar Ilmu Komunikasi, Teori Komunikasi, Psikologi Komunikasi, Komunikasi Kontekstual, Komunikasi Massa. Konten yang dikembangkan bervariasi berupa video, animasi, gambar, power point dan sebagainya yang memudahkan mahasiswa untuk memahami materi. Disamping pengembangan mata kuliah, keterampilan yang dimaksud dalam penelitian ini berupa kemampuan dosen dalam menciptakan pembelajaran yang mandiri.

Dalam usahanya untuk menuju tujuan pembelajaran mandiri tadi maka Prodi Ilmu Komunikasi UNIDA Gontor harus mampu menghadirkan cara-cara pembelajaran yang aktif. Teori Dewey "Learning by Doing” (18591952) menjelaskan bahwa peran mahasiswa dan dosen dalam konteks belajar aktif menjadi sangat penting. Menurut teori ini dosen memiliki peranan antara lain: berperan aktif sebagai fasilitator yang membantu memudahkan mahasiswa belajar, sebagai narasumber yang mampu mengundang pemikiran dan daya kreasi mahasiswa, sebagai pengelola yang mampu merancang dan melaksanakan kegiatan belajar bermakna, dan dapat mengelola sumber belajar 
yang diperlukan. Sedangkan mahasiswa juga terlibat dalam proses belajar bersama dosen, karena mahasiswa dibimbing, belajar dan dilatih menjelajah, mencari, mempertanyakan sesuatu, menyelidiki jawaban atas suatu pertanyaan, mengelola dan menyampaikan hasil perolehannya secara komunikatif. Bahkan sekarang banyak mahasiswa yang diikutkan dalam penelitian dosen (aktif membantu dalam penelitian dosen).

Proses pembelajaran aktif atau belajar aktif merupakan suatu pendekatan dalam pengelolaan sistem pembelajaran melalui cara-cara belajar yang aktif menuju belajar mandiri. Kemampuan belajar mandiri merupakan tujuan akhir dari belajar aktif. Keikutsertaan dan peran serta mahasiswa dan dosen dalam konteks belajar aktif merupakan hal yang sangat penting. Belajar aktif merupakan pendekatan yang lain dari pada gambaran rutin perkuliahan yang sudah ada, misalnya ceramah (kuliah mimbar). Pendekatan belajar aktif didukung dengan cara pengelolaan kelas yang beragam, pemanfaatan sumber belajar yang beraneka ragam dan pemberian kesempatan kepada setiap mahasiswa untuk berkembang secara optimal sesuai dengan kemampuannya.

Pemanfaatan e-learning diharapkan mampu menjadi sebuah inovasi pembelajaran yang tidak hanya terpaku di dalam kelas tetapi dapat dilakukan secara virtual tanpa harus bertatap muka. Disamping itu, penggunaan e-learning juga merupakan bentuk pemanfaatan media digital sebagai sumber belajar mahasiswa. Yang tidak kalah pentingnya adalah pemanfaatan e-learning dalam pembelajaran akan dapat memberikan kesempatan yang luas kepada mahasiswa untuk berkembang secara optimal dikarenakan dengan konten yang sudah di unggah oleh dosen maka mahasiswa mampu mempelajarinya berulang kali dan juga dapat mendiskusikannya melalui forum.

Komponen ketiga dari pembelajaran kreatif selain keahlian dan keterampilan adalah motivasi instrinsik yang merupakan dorongan untuk melakukan sesuatu semata demi kesenangan melakukannya, bukan karena kompensasi atau hadiah (Teresa dalam Goleman dkk, 2005). Berdasarkan hasil penelitian menunjukkan bahwa motivasi dosen-dosen program studi Ilmu Komunikasi UNIDA Gontor dalam mengembangkan konten pembelajaran dan memanfaatkan e-learning dalam proses pembelajaran murni untuk meningkatkan hasil belajar mahasiswa, bukan karena motif berupa materi atau bentuk penghargaan lain misalnya berupa pujian.

Disamping itu, jiwa keikhlasan yng merupakan panca jiwa pondok harus dan wajib dimiliki oleh seluruh civitas akademika Universitas Darussalam Gontor termasuk para dosen. Keikhlasan menurut pendiri Gontor mengandung pengertian sepi ing pamrih (tidak karena didorong oleh keinginan memperoleh keuntungan-keuntungan tertentu) semata-mata karena ibadah. Hal ini meliputi segenap suasana kehidupan di Pondok Pesantren. Kyai ikhlas mengajar, para santri ikhlas dalam belajar, dan sebagainya. Dengan demikian terdapatlah suasana hidup yang harmonis antara Kyai, rektor, dosen yang disegani dan santri/ mahasiswa yang taat dan penuh cinta serta hormat dengan segala keikhlasannya. Termasuk juga dalam proses pembelajaran.

\section{Simpulan}

Dari hasil analisis dan pembahasan, dapat disimpulkan bahwa model edukasi kreatif pesantren dalam hal iniUniversitas Darussalam Gontor dilakukan melalui pemanfaatan e-learning dalam proses pembelajaran matakuliah dasar. Komponen pembelajaran kreatif terdiri dari tiga hal yakni keahlian, kemampuan, dan motivasi intrinsik. Tiga komponen tersebut perlu dimaksimalkan untuk dapat dijadikan sebagai model pembelajaran kreatif di pesantren. Kontribusi dari penelitian ini berupa model edukasi kreatif pesantren melalui pemanfaatan e-learning di era digital.

\section{Daftar Pustaka}

T.L Friedman. (2007). The world is flat 3.0: A Brief History Of The Twenty 
first Century. New York: Picador. Hamied, Fuad Abdul. (2009). Model PembelajaranInovatif Di Era Global (SuatuKajianPerbandingan Di Negara Maju).JurnalIlmiahKependidikan, Vol 1,No 2Maret 2009, ISSN: 1979-6668.

B. Trilling \&Fadel, C. (2009). 21st Century skills: learning for life in our times. San Fransisco: Josey-Bass. Wijaya, EstitikaYuni dan Dwi Agus Sudjimat dan Amat Nyoto.(2016). Transformasi Pendidikan Abad 21 Sebagai Tuntutan Pengembangan Sumber Daya Manusia di Era Global. Prosiding Seminar Nasional PendidikanMatermatika. UniversitasKanjuruhan Malang. Barokati, NisauldanFajarAnnas. (2013). PengembanganPembelajaranBerbasis Blended Learning Pada Mata KuliahPemrogramanKomputer (StudiKasusUNISDA Lamongan).Jurnal SISFO, Vol.7 No.2, eISSN: 2301- 4273.
Agustina, Merry. (2013). Pemanfaatan E-Learning Sebagai MediaPembelajaran. Prosiding Seminar Nasional Aplikasi Teknologi Informasi, ISSN: 19075022, Yogyakarta, Juni 2013, pp.8-12. Goleman, Daniel.,dkk.(2005). The Creative Spirit (Terjemah). Bandung : Penerbit MLC.

Staff Skretaris PMDG Ponorogo. (2017). Serba Serbi Serba Singkat Pondk Modern Darussalam Gontor. Ponorogo: Percetakan Darussalam. Nurhakim, Moh. (2011). Imam Zarkasyi Dan Pembaharuan Pesantren :Rekonstruksi Aspek Kurikulum, MenejemenDan Etika Pendidikan. Jurnal PROGRESIVA Vol. 5, No.1, Desember 2011. Rosenberg, Marc. J. (2001) E-Learning: Strategies for Delivering Knowledge In The Digital Age. New York: Mc.Graw-Hill Comapnies. pp. 28. 